\title{
Wavelength Conversion Lanthanide(III)-cored Complex for Highly Efficient Dye-sensitized Solar Cells
}

\author{
Jung Hwan Oh, Hae Min Song, Yu Kyung Eom, Jung Ho Ryu, Myung Jong Ju, and Hwan Kyu Kim* \\ Department of Advanced Materials Chemistry and Center for Advanced Photovoltaic Materials (ITRC) and \\ Center for Next Generation Photovoltaic System (WCU), Korea University, Jochiwon, Chung Nam 339-700, Korea \\ *E-mail:hkk777@korea.ac.kr \\ Received June 23, 2011, Accepted July 7, 2011
}

\begin{abstract}
Lanthanide(III)-cored complex as a wavelength conversion material has been successfully designed and synthesized for highly efficient dye-sensitized solar cells, for the first time, since light with a short wavelength has not been effectively used for generating electric power owing to the limited absorption of these DSSCs in the UV region. A black dye (BD) was chosen and used as a sensitizer, because BD has a relatively weak light absorption at shorter wavelengths. The overall conversion efficiency of the BD/WCM device was remarkably increased, even with the relatively small amount of WCM added to the device. The enhancement in $V_{\text {oc }}$ by WCM, like DCA, could be correlated with the suppression of electron recombination between the injected electrons and $\mathrm{I}_{3}{ }^{-}$ions. Furthermore, the short-circuit current density was significantly increased by WCM with a strong UV light-harvesting effect. The energy transfer from the Eu(III)-cored complex to the $\mathrm{TiO}_{2}$ film occurred via the dye, so the number of electrons injected into the $\mathrm{TiO}_{2}$ surface increased, i.e., the short-circuit current density was increased. As a result, BD/WCM-sensitized solar cells exhibit superior device performance with the enhanced conversion efficiency by a factor of 1.22 under AM 1.5 sunlight: The photovoltaic performance of the BD/WCM-based DSSC exhibited remarkably high values, $J_{\text {sc }}$ of $17.72 \mathrm{~mA} / \mathrm{cm}^{2}, V_{\text {oc }}$ of 720 $\mathrm{mV}$, and a conversion efficiency of $9.28 \%$ at $100 \mathrm{~mW} \mathrm{~cm}^{-2}$, compared to a standard DSSC with $J_{\mathrm{sc}}$ of 15.53 $\mathrm{mA} / \mathrm{cm}^{2}, V_{\text {oc }}$ of $689 \mathrm{mV}$, and a conversion efficiency of $7.58 \%$ at $100 \mathrm{~mW} \mathrm{~cm}^{-2}$. Therefore, the Eu(III)-cored complex is a promising candidate as a new wavelength conversion coadsorbent for highly efficient dyesensitized solar cells to improve UV light harvesting through energy transfer processes. The abstract should be a single paragraph which summaries the content of the article
\end{abstract}

Key Words : Europium(III)-cored complex, Wavelength conversion material, Energy transfer, UV light harvesting, Dye-sensitized solar cells

\section{Introduction}

The luminescent lanthanide complexes have been of great interest due to their potential photonic applications, such as planar waveguide amplifiers, light-emitting diodes plastic lasers, and luminescent probes. ${ }^{1-8}$ Very recently, lanthanide(III)cored complex has been successfully utilized as a wavelength conversion material for highly efficient dye-sensitized solar cells, since light with a short wavelength has not been effectively used for generating electric power owing to the limited absorption of these DSSCs in the UV regions, for the first time. For over the past decades, dye-sensitized solar cells (DSSCs) have attracted much attention as a low-cost alternative to conventional inorganic photovoltaic devices. ${ }^{9-13}$

Typically, DSSCs are composed of a photoactive $\mathrm{TiO}_{2}$ anode coated with photosensitizers (sensitizing dyes), redox electrolytes and a passive cathode (n-type DSSCs). On the basis of continuous material innovation and device engineering, a state of the art DSSC has achieved a validated efficiency of $12 \%$ measured at the AM1.5G conditions. ${ }^{14-17}$ Efficient operation of the DSSC device relies upon the minimization of the interfacial charge recombination losses. There are two major recombination losses of importance in DSSCs, in which electrons photoinjected into the $\mathrm{TiO}_{2}$ film can recombine with either dye cations or redox couple at the $\mathrm{TiO}_{2} /$ dye/electrolyte interface. Such charge recombination leads to losses in both $V_{\mathrm{oc}}$ and $J_{\mathrm{sc}}$, resulting in the decrease in power conversion efficiency. To improve the photovoltaic performance of the DSSCs by slowing recombination, several strategies involving the treatment of the $\mathrm{TiO}_{2}$ surface have been employed by the insertion of the metal oxide blocking layer ${ }^{18,19}$ and the adsorption of certain organic molecules, so-called co-adsorbents. ${ }^{20-22}$ Typically both the incident photon-to-electron conversion efficiency (IPCE) and the photocurrents in organic based devices, including some $\mathrm{Ru}$ complexes, were improved by addition of deoxycholic acid (DCA) to break up dye aggregates. ${ }^{23-29}$ The addition of co-adsorbents results in the formation of mixed monolayer which should be more tightly packed than when the sensitizer is adsorbed alone, providing a more effective insulated barrier for the back electron transfers from $\mathrm{TiO}_{2}$ conduction band to triiodide electrolyte. ${ }^{20-22}$ Such unwanted redox process is retarded by the hydrophobic spacer and, as a result, the dark current is reduced and high $V_{\mathrm{oc}}$ is obtained. ${ }^{30,31}$ Still, DSSCs are the most promising devices for the energy conversion of sunlight to electric power. 


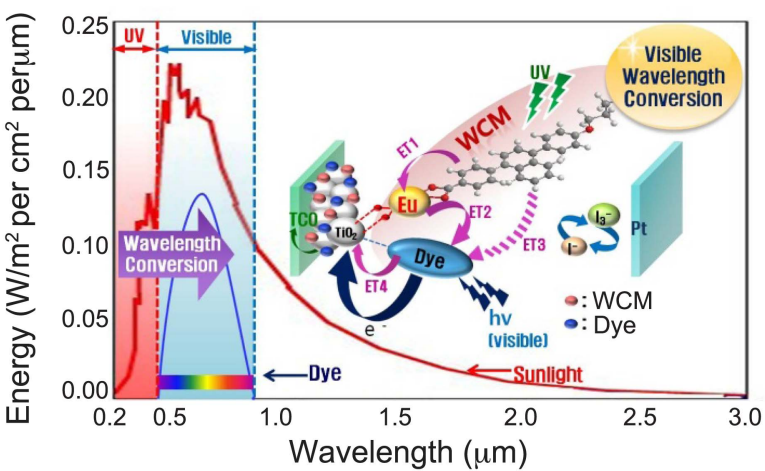

Scheme 1. The spectrum distribution of sunlight and illustration of intermolecular energy transfer between the WCM based on a europium(III) complex and the dye in the DSSCs. ET1 means energy transfer from naphthalene ligands to $\mathrm{Eu}^{3+}$ ions, and ET2 means energy transfer from $\mathrm{Eu}^{3+}$ ions to dyes. ET3 means energy transfer from naphthalene ligands to dyes, ET4 means electron injection into $\mathrm{TiO}_{2}$.

However, light with a short wavelength is not effectively used for generating electric power owing to the limited absorption of these cells in the UV region. The conversion efficiency of DSSCs can be improved by utilizing wavelength conversion materials (WCMs) as an alternative way to improve UV light harvesting, which absorb light at shorter wavelengths and emit light at longer wavelengths (Scheme 1), since WCMs based on Eu (III)-cored complexes have been used to enhance the performance of silicon-based solar cells. ${ }^{32,33}$

In the present study, we first investigated a wavelength conversion Eu (III)-cored complex (WCM) as a UV lightharvesting coadsorbent to play the major role on photovoltaic performance of the DSSCs based on black dye (BD) (see Scheme 2). BD was chosen and used as a sensitizer without further purification received from Solaronix, S.A, because $\mathrm{BD}$ has a relatively weak light absorption at shorter wavelengths. The redox liquid electrolyte contains $0.1 \mathrm{M}$ LiI, 0.05 M I $2,0.6$ M 1,2-dimethyl-3-n-propylimidazolium iodide (DMPII), and 0.5 M 4-tert-butylpyridine (tBP) using dehydrated $\mathrm{CH}_{3} \mathrm{CN}$ as a solvent. Here an $\mathrm{Eu}(\mathrm{III})$-cored complex based on 4-(4-(4-(2-ethylhexyl-oxy)phenyl) naphthalen-1-yl)benzoic acid as a WCM, which absorbs the UV

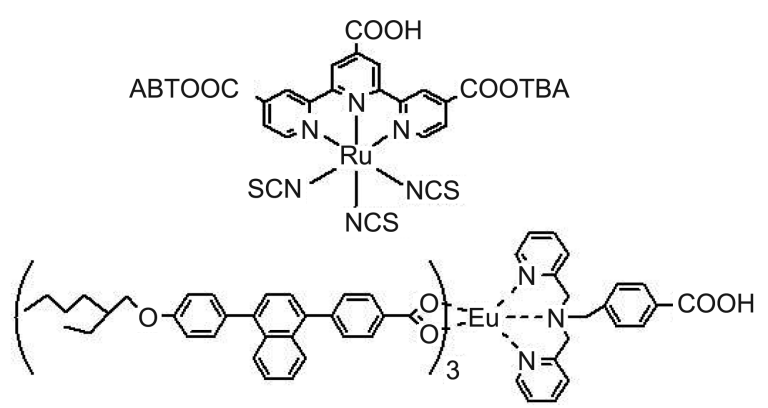

Scheme 2. Molecular structures of BD (top) and naphthalenebased WCM, Eu(III)-cored complex (bottom). TBA stands for tetrabutylammonium.
Table 1. Photovoltaic performances of the DSSCs with different coadsorbents under the AM 1.5 full sunlight $\left(100 \mathrm{~mW} \mathrm{~cm}^{-2}\right)$

\begin{tabular}{lccccc}
\hline Device & $\begin{array}{c}\text { Relative ratio of } \\
\text { dye adsorbed } \\
\text { amount }\end{array}$ & $\begin{array}{c}J_{\text {sc }} \\
{\left[\mathrm{mA} \mathrm{cm}^{-2}\right]}\end{array}$ & $\begin{array}{c}V_{\text {oc }} \\
{[\mathrm{mV}]}\end{array}$ & $\begin{array}{c}F F \\
{[\%]}\end{array}$ & $\begin{array}{c}\eta \\
{[\%]}\end{array}$ \\
\hline $\mathrm{BD}$ & 1.00 & 15.53 & 689 & 70.70 & 7.58 \\
$\mathrm{BD} / \mathrm{DCA}$ & 0.82 & 16.59 & 722 & 71.35 & 8.54 \\
$\mathrm{BD} / \mathbf{W C M}^{b}$ & 0.69 & 17.72 & 720 & 72.79 & 9.28 \\
$\mathrm{BD} / \mathbf{W C M}{ }^{a}$ & 0.75 & 16.93 & 708 & 72.35 & 8.69 \\
$\mathbf{W C M}$ & - & 0.41 & 487 & 77.00 & 0.15 \\
\hline
\end{tabular}

$[\mathrm{BD}]=0.2 \mathrm{mM} ;[\mathrm{DCA}]=20 \mathrm{mM} .{ }^{a}[\mathrm{WCM}]=0.1 \mathrm{mM} \cdot{ }^{b}[\mathrm{WCM}]=0.2$ $\mathrm{mM}$

region of the sun-light spectrum was depicted in Scheme 2. The introduction of the bulky ethylhexyloxy group into naphthalene ligand was achieved in order to enhance its solubility on organic solvents as well as the potential of inserting barrier layer to retard recombination losses. 4-((Bis(pyridin-2-ylmethyl)-amino)methyl)benzoic acid was synthesized to form 9-coordination with $\mathrm{Eu}(\mathrm{III})$ ions and provides an anchoring group of $-\mathrm{COOH}$ onto a $\mathrm{TiO}_{2}$ nanocrystalline film. ${ }^{34-39}$ The relative ratio of dye amount adsorbed on $\mathrm{TiO}_{2}$ films was estimated from the UV-vis spectra of black dye adsorbed on $\mathrm{TiO}_{2}$ photoanode at different co-adsorbents and summarized in Table 1 . When dye with DCA or WCM was coadsorbed on the $\mathrm{TiO}_{2}$ film, the deprotonation of carboxylic acid group in the dye induces the less adsorption of dye molecules on $\mathrm{TiO}_{2}$ surface due to the electrostatic repulsion of negatively charged carboxylic groups. Moreover, the lower amount of dye adsorption with WCM complex than DCA is mainly due to bigger molecular size of WCM. . $^{40-43}$

\section{Experimental}

Materials. All reagents are from Aldrich and TCI and were used as received except tetrahydrofuran (THF) which was freshly distilled from sodium-benzophenone under $\mathrm{N}_{2}$. Methyl 4-((bis(pyridin-2-ylmethyl)amino)methyl)benzoate and 4-((bis(pyridin-2-ylmethyl) amino)methyl)benzoic acid (neutral ligand) (1) were prepared according to the literature. ${ }^{44}$

Measurements. ${ }^{1} \mathrm{H}$ NMR, ${ }^{13} \mathrm{C}$ NMR were recorded with the use of Varian Oxford $300 \mathrm{MHz}$ spectrometer; chemical shifts were reported in ppm units with tetramethylsilane as an internal standard. Infrared spectra were measured on $\mathrm{KBr}$ pellets using a Perkin-Elmer Spectrometer. The mass spectra were taken by a JEOL JMS-AX505WA mass spectrometer. The absorption and photoluminescence spectra were recorded on a Perkin-Elmer Lambda $2 \mathrm{~S}$ UV-visible spectrometer and a Perkin LS fluorescence spectrometer, respectively. Photovoltaic data were measured using a $1000 \mathrm{~W}$ xenon light source (Oriel, 91193) that was focused to give $1000 \mathrm{~W} / \mathrm{m}^{2}$, the equivalent of one sun at Air Mass (AM) $1.5 \mathrm{G}$, at the surface of the test cell. The light intensity was adjusted with a $\mathrm{Si}$ solar cell that was double-checked with an NREL-calibrated Si solar cell (PV Measurement Inc.). The applied potential and cell current were measured using a Keithley model 2400 
digital source meter. The current-voltage characteristics of the cell under these conditions were determined by biasing the cell externally and measuring the generated photocurrent. This process was fully automated using Wavemetrics software.

$\mathrm{TiO}_{2}$ Electrode Preparation. FTO glass plates (Pilkington TEC Glass-TEC 8, Solar $2.3 \mathrm{~mm}$ thickness) were cleaned in a detergent solution using an ultrasonic bath for 30 min, rinsed with water and ethanol. The FTO glass plates were immersed in $40 \mathrm{mM} \mathrm{TiCl}_{4}$ (aqueous) at $70{ }^{\circ} \mathrm{C}$ for $30 \mathrm{~min}$ and washed with water and ethanol. A transparent nanocrystalline layer on the FTO glass plate was prepared by doctor blade printing $\mathrm{TiO}_{2}$ paste (Solaronix, Ti-Nanoxide T/ $\mathrm{SP}$ ) and then dried for $2 \mathrm{~h}$ at $25^{\circ} \mathrm{C}$. The $\mathrm{TiO}_{2}$ electrodes were gradually heated under an air flow at $325^{\circ} \mathrm{C}$ for $5 \mathrm{~min}$, at $375{ }^{\circ} \mathrm{C}$ for $5 \mathrm{~min}$, at $450{ }^{\circ} \mathrm{C}$ for $15 \mathrm{~min}$, and at $500{ }^{\circ} \mathrm{C}$ for $15 \mathrm{~min}$. The thickness of the transparent layer was measured by using an Alpha-step 250 surface profilometer (Tencor Instruments, San Jose, CA), a paste for the scattering layer containing $400 \mathrm{~nm}$ sized anatase particles (CCIC, PST400C) was deposited by doctor blade printing and then dried for $2 \mathrm{~h}$ at $25^{\circ} \mathrm{C}$. The $\mathrm{TiO}_{2}$ electrodes were gradually heated under an air flow at $325^{\circ} \mathrm{C}$ for $5 \mathrm{~min}$, at $375^{\circ} \mathrm{C}$ for $5 \mathrm{~min}$, at $450{ }^{\circ} \mathrm{C}$ for $15 \mathrm{~min}$, and at $500{ }^{\circ} \mathrm{C}$ for $15 \mathrm{~min}$. The resulting layer was composed of $8 \mu \mathrm{m}$ thickness of transparent layer and $8 \mu \mathrm{m}$ thickness of scattering layer, which were treated again by $\mathrm{TiCl}_{4}$ at $70{ }^{\circ} \mathrm{C}$ for $30 \mathrm{~min}$ and sintered at $500{ }^{\circ} \mathrm{C}$ for 30 min.

Dye-sensitized Solar Cell Fabrication. The dyedeposited $\mathrm{TiO}_{2}$ film was used as a working electrode. The FTO plate (Pilkington TEC Glass-TEC 8, Solar $2.3 \mathrm{~mm}$ thickness) for a counter electrode was cleaned with ultrasonic bath in $\mathrm{H}_{2} \mathrm{O}$, acetone and $0.1 \mathrm{M}$ aqueous $\mathrm{HCl}$, subsequently. The counter electrode was prepared by coating with a drop of $\mathrm{H}_{2} \mathrm{PtCl}_{6}$ solution ( $2 \mathrm{mg}$ of Pt in $1 \mathrm{~mL}$ of ethanol) on a FTO plate and heating at $400{ }^{\circ} \mathrm{C}$ for $15 \mathrm{~min}$. The dye-deposited $\mathrm{TiO}_{2}$ electrode and Pt coated counter electrode were assembled into a sealed sandwich-type cell by heating at $80{ }^{\circ} \mathrm{C}$ with a hot-melt ionomer film (Surlyn SX 1170-25, Solaronix) as a spacer between the electrodes. A drop of electrolyte solution (electrolyte of 0.6 M DMPII, 0.05 M I $2,0.1 \mathrm{M} \mathrm{LiI}$, and 0.5 $\mathrm{M}$ tertbutylpyridine in acetonitrile) was placed on the drilled hole in the counter electrode of the assembled cell and was driven into the cell via vacuum backfilling. Finally, the hole was sealed using additional Surlyn and a cover glass $(0.1$ $\mathrm{mm}$ thickness).

\section{Syntheses Procedure.}

4-((Bis(pyridin-2-ylmethyl)amino)methyl)benzoic acid (neutral ligand) (1) Methyl 4-((bis(pyridin-2-ylmethyl) amino)methyl) benzoate was Prepared As Follows: $\mathrm{NEt}_{3}$ $(1.4 \mathrm{~mL}, 10.04 \mathrm{mmoL})$ was added to a solution of bis(2picolyl)amine $(1.18 \mathrm{~mL}, 10.04 \mathrm{mmol})$ and methyl $p$-(bromomethyl) benzoate $(2.3 \mathrm{~g}, 10.04 \mathrm{mmol})$ in THF $(80 \mathrm{~mL})$, and the mixture was refluxed for $1.5 \mathrm{~h}$. The mixture was allowed to reach room temperature and filtered to remove a white precipitate. After removal of the solvent, the oily residue was dissolved in $\mathrm{Et}_{2} \mathrm{O}(80 \mathrm{~mL})$ and filtered to remove a red solid. Evaporation of the solvent yielded $2 \mathrm{~g}(83 \%)$ of a orange oil, which was used as such in the next step. A solution of $\mathrm{NaOH}(0.8 \mathrm{~g}, 20 \mathrm{mmol})$ in $5 \mathrm{~mL}$ of $\mathrm{H}_{2} \mathrm{O}$ was added to a solution of methyl 4-((bis(pyridin-2-ylmethyl)amino)methyl) benzoate $(1.4 \mathrm{~g}, 4.0 \mathrm{mmol})$ in $\mathrm{MeOH}(20 \mathrm{~mL})$, and the mixture was stirred for $2 \mathrm{~h}$ at room temperature. The $\mathrm{pH}$ was neutralized with $2 \mathrm{M} \mathrm{HCl}$, followed by removal of the solvent under reduced pressure. The white residue was triturated with $\mathrm{CHCl}_{3}(200 \mathrm{~mL}$ ), followed by filtration to remove $\mathrm{NaCl}$. The $\mathrm{CHCl}_{3}$ solution was dried with $\mathrm{MgSO}_{4}$. Removal of the solvent under reduced pressure afforded a yellow oil, to which $\mathrm{CH}_{3} \mathrm{CN}(30 \mathrm{~mL})$ was added, followed by stirring. After approximately min, a white precipitate formed. The solution was stored at $0{ }^{\circ} \mathrm{C}$ for $2 \mathrm{~h}$, to effect further precipitation and the white solid was then isolated by filtration and dried in vacuo. Yield $0.6 \mathrm{~g}(53 \%)$. Anal. Calcd. for $\mathrm{C}_{20} \mathrm{H}_{19} \mathrm{~N}_{3} \mathrm{O}_{2}$ Exact Mass $=333.3, \mathrm{IR}(\mathrm{KBr}) \mathrm{cm}^{-1}=1698(\mathrm{~m}) v_{\mathrm{C}=\mathrm{O}} .{ }^{1} \mathrm{H}$ NMR $\left(\mathrm{CDCl}_{3}, 300 \mathrm{MHz}\right) \delta 12.82(\mathrm{~s}, 1 \mathrm{H}), 8.49(\mathrm{~d}, 2 \mathrm{H}, J=4.2 \mathrm{~Hz})$, $7.91(\mathrm{~d}, 2 \mathrm{H}, J=8.4 \mathrm{~Hz}), 7.77(\mathrm{t}, 2 \mathrm{H}, J=7.6 \mathrm{~Hz}), 7.55(\mathrm{~d}, 2 \mathrm{H}$, $J=9.0 \mathrm{~Hz}), 7.54(\mathrm{~d}, 2 \mathrm{H}, J=7.8 \mathrm{~Hz}), 7.24(\mathrm{~m}, 4 \mathrm{H}), 3.71$ $(\mathrm{s}, 6 \mathrm{H}),{ }^{13} \mathrm{C} \mathrm{NMR}\left(\mathrm{CDCl}_{3}, 226.4 \mathrm{MHz}\right) \delta 169.3(\mathrm{C}=\mathrm{O}), 159.7$, $148.3,143.8,137.5,131.0,128.7,123.5,122.7,122.5,59.7$, 58.6 .

4-(4-(4-Hydroxyphenyl)naphthalen-1-yl)benzonitrile (2): 4-(4-(4-methoxyphenyl)naphthalen-1-yl)benzonitrile (4.0 g $12.93 \mathrm{mmol}$ ) was dissolved in dry $\mathrm{CH}_{2} \mathrm{Cl}_{2}$ under nitrogen atmosphere. The solution was cooled to $-78{ }^{\circ} \mathrm{C}$, and then $\mathrm{BBr}_{3}(3.38 \mathrm{~mL}, 35.78 \mathrm{mmol})$ was slowly added to the reaction mixture. After addition, the mixture was allowed to worm to room temperature as it stirred overnight. Water added to deactivate any unreacted $\mathrm{BBr}_{3}$. The solvent was evaporated, and the crude product was washed with hexane, yielding a yellow solid. Yield 95\% Anal. Calcd. for $\mathrm{C}_{23} \mathrm{H}_{15} \mathrm{NO}$ Exact Mass: $321.12 .{ }^{1} \mathrm{H} \mathrm{NMR}\left(\mathrm{CDCl}_{3}, 300 \mathrm{MHz}\right)$ $\delta 9.67(\mathrm{~s}, 1 \mathrm{H}), \delta 8.03-8.00(\mathrm{~d}, 2 \mathrm{H}, J=9.0 \mathrm{~Hz}), \delta 7.79-7.71(\mathrm{~m}$, $4 \mathrm{H}), \delta$ 7.55-7.45 (m, 4H), $\delta$ 7.33-7.30 (d, $2 \mathrm{H}, J=9.0 \mathrm{~Hz})$, $\delta$ 6.95-6.92 (d, $2 \mathrm{H}, J=9.0 \mathrm{~Hz})$.

4-(4-(4-(2-Ethylhexyloxy)phenyl)naphthalen-1yl) benzonitrile (3): To a mixture of 4-(4-(4-hydroxyphenyl)naphthalen1-yl)benzonitrile $(16.8 \mathrm{mmol}$ ) and 3-(bromomethyl)heptane $(16.8 \mathrm{mmol})$ in $\mathrm{N}, \mathrm{N}$-dimethylformamide $(100 \mathrm{~mL})$ was added $\mathrm{K}_{2} \mathrm{CO}_{3}(18.8 \mathrm{mmol})$. The mixture was heated at reflux for $24 \mathrm{~h} . \mathrm{CH}_{2} \mathrm{Cl}_{2}(100 \mathrm{~mL})$ was added to the mixture and the organic layer was washed with brine three times. The organic layer was dried over anhydrous $\mathrm{MgSO}_{4}$ and solvent was removed under vacuum. Pure product was obtained by column chromatography with $\mathrm{CH}_{2} \mathrm{Cl}_{2}$ in hexane. Yield $50 \%$. Anal. Calcd. for $\mathrm{C}_{31} \mathrm{H}_{31} \mathrm{NO}$ Exact Mass: 433.24. ${ }^{1} \mathrm{H}$ NMR $\left(\mathrm{CDCl}_{3}, 300 \mathrm{MHz}\right) \delta 8.05-8.02(\mathrm{~m}, 2 \mathrm{H}), \delta$ 7.84-7.83 (d, 4H, $J=3.0 \mathrm{~Hz}), \delta 7.72-7.66(\mathrm{~d}, 2 \mathrm{H}, J=18 \mathrm{~Hz}), \delta \quad 7.48-7.41(\mathrm{~m}$, $4 \mathrm{H}), \delta$ 7.07-7.04 (d, $2 \mathrm{H}, J=9.0 \mathrm{~Hz}), \delta 3.95-3.94(\mathrm{~d}, 2 \mathrm{H}, J=$ $3.0 \mathrm{~Hz}), \delta 1.82-1.78(\mathrm{~m}, 1 \mathrm{H}), \delta \quad 1.60-1.45(\mathrm{~m}, 8 \mathrm{H}), \delta 0.92-$ $0.86(\mathrm{~m}, 6 \mathrm{H})$.

4-(4-(4-(2-Ethylhexyloxy)phenyl)naphthalen-1-yl)benzoic acid (central ligand) (4): $\mathrm{KOH}$ (8 equiv.) was added to a solution of 4-(4-(4-(2-ethylhexyloxy)phenyl)naphthalen-1-yl) benzonitrile (1 equiv.) in 2-ethoxyethanol/ $\mathrm{H}_{2} \mathrm{O}(7 / 3)$. The 
reaction mixture was stirred for $12 \mathrm{~h}$ at reflux temperature. The reaction mixture was evaporated to dryness to vacuo. The residual was dissolved with water and then acidified with $\mathrm{HCl}$. This solid was washed sequentially with water, and hexane, giving a yellowish solid. Yield $60 \%$. Anal. Calc. for $\mathrm{C}_{31} \mathrm{H}_{32} \mathrm{O}_{3}$ Exact Mass: $452.24 \mathrm{MS}: \mathrm{m} / z$ 452.2 [ $\left.\mathrm{M}^{+}\right]$. IR $(\mathrm{KBr}): \mathrm{cm}^{-1}=1699(\mathrm{~m}) v_{\mathrm{C}=\mathrm{O}},{ }^{1} \mathrm{H}$ NMR $\left(\mathrm{CDCl}_{3}, 300 \mathrm{MHz}\right)$ $\delta 13.08(\mathrm{~s}, 1 \mathrm{H}) \delta 8.12-8.09(\mathrm{~m}, 2 \mathrm{H}), \delta 7.94-7.91(\mathrm{~d}, 4 \mathrm{H}, J=$ $9.9 \mathrm{~Hz}), \delta 7.86-7.82(\mathrm{~d}, 2 \mathrm{H}, J=11.4 \mathrm{~Hz}), \delta 7.66-7.63(\mathrm{~m}$, $2 \mathrm{H}), \delta$ 7.46-7.44 (d, 2H, $J=5.4 \mathrm{~Hz}), \delta 7.13-7.10(\mathrm{~d}, 2 \mathrm{H}, J=$ $8.7 \mathrm{~Hz}), \delta 3.96-3.94(\mathrm{~d}, 2 \mathrm{H}, J=5.4 \mathrm{~Hz}), \delta 1.74-1.72(\mathrm{~m}$, $1 \mathrm{H}), \delta 1.56-1.43(\mathrm{~m}, 8 \mathrm{H}), \delta 0.95-0.88(\mathrm{~m}, 6 \mathrm{H}) .{ }^{13} \mathrm{C} \mathrm{NMR}$ $\left(\mathrm{CDCl}_{3}, 226.4 \mathrm{MHz}\right) \delta 169.3,156.3,141.6,135.6,133.6$, $130.8,129.1,128.5,128.3,128.0,127.8,126.3,125.6$, 114.9, 74.9, 40.3, 30.9, 29.6, 24.9, 23.0, 14.1, 11.9 .

Eu(III)-cored Complex (WCM) (5): Eu(III)-cored complex was synthesized using synthetic methods previously developed by our group. ${ }^{24}$ A mixture of 4 (3.0 equiv.), and $\mathrm{KH}$ (3.0 equiv.) was stirred in freshly distilled THF at room temperature for overnight until there was no more $\mathrm{H}_{2}$ gas to generate. After the completion of salts, the methanol solution of anhydrous $\mathrm{EuCl}_{3}$ (1.0 equiv.) and appropriated 1 (1.1 equiv.) added to the reaction solution, and then stirred for 2 days. The resulting solution was filtered and the solvents were removed. The resultant solid was washed sequentially with methanol, hexane and diethyl ether, yielding a yellowish solid. Yield 66\%. NMR investigations showed that signal from the central ligands are significantly shifted upfield and broadened due to coordination of the paramagnetic metal centre. ${ }^{1} \mathrm{H} \mathrm{NMR}\left(\mathrm{CDCl}_{3}, 300 \mathrm{MHz}\right) \delta$ $12.93(\mathrm{~s}, 1 \mathrm{H}), \delta$ 7.99-7.03 (m, 54H), $\delta 3.94-3.92(\mathrm{~m}, 12 \mathrm{H}), \delta$ 1.79-1.77 (m, 3H), $\delta 1.57-1.37(\mathrm{~m}, 24 \mathrm{H}), \delta 1.00-0.93(\mathrm{~m}$, 18H) IR (KBr): cm ${ }^{-1}=3415(-\mathrm{OH}), 1687(\mathrm{C}=\mathrm{O}), 1405$ (C$\mathrm{N}), 1244$ (C-O). Exact Mass: $1839.75 \mathrm{~m} / \mathrm{z}$, Anal. Calcd. for $\mathrm{C}_{113} \mathrm{H}_{112}$ EuN $_{3} \mathrm{O}_{11}$ and $\mathrm{C}, 73.76 ; \mathrm{H}, 6.14 ; \mathrm{N}, 2.28 ; \mathrm{O}, 9.56$; $\mathrm{Eu}, 8.26$; Found: C, 73.26; H, 6.10; N, 2.30; O, 10.18; Eu, 8.16 .

\section{Results and Discussion}

The synthetic route for central and neutral ligands and corresponding lanthanide(III)-cored complex is illustrated on Scheme 1. Compound 1 was prepared from 4((bis(pyridin-2-ylmethyl)amino)methyl) benzoate as a intermediate in which $\mathrm{OCH}_{3}$ group was hydrolysized. Also, compound 4 of (4-(4-(4-(2-ethylhexyloxy)phenyl) naphthalen1-yl)benzoic acid as a central ligand was prepared by Suzuki coupling reaction between boronic acid and substituted bromonaphthalene. Firstly, the methoxy group of $\mathbf{3}$ was demethylated with $\mathrm{BBr}_{3}$. The hydroxylated central ligand was then coupled with ethyllhexylbromide compound 3. Secondly, the $-\mathrm{CN}$ group was hydrolysized, yielding the compound 4 . All compounds were characterized by FT-IR, ${ }^{1} \mathrm{H}-\mathrm{NMR}$ (Figure S1), EI Mass spectroscopy (Figure S2), absorption and emission spectroscopy (Figure S4 and S5 in Supporting Information).

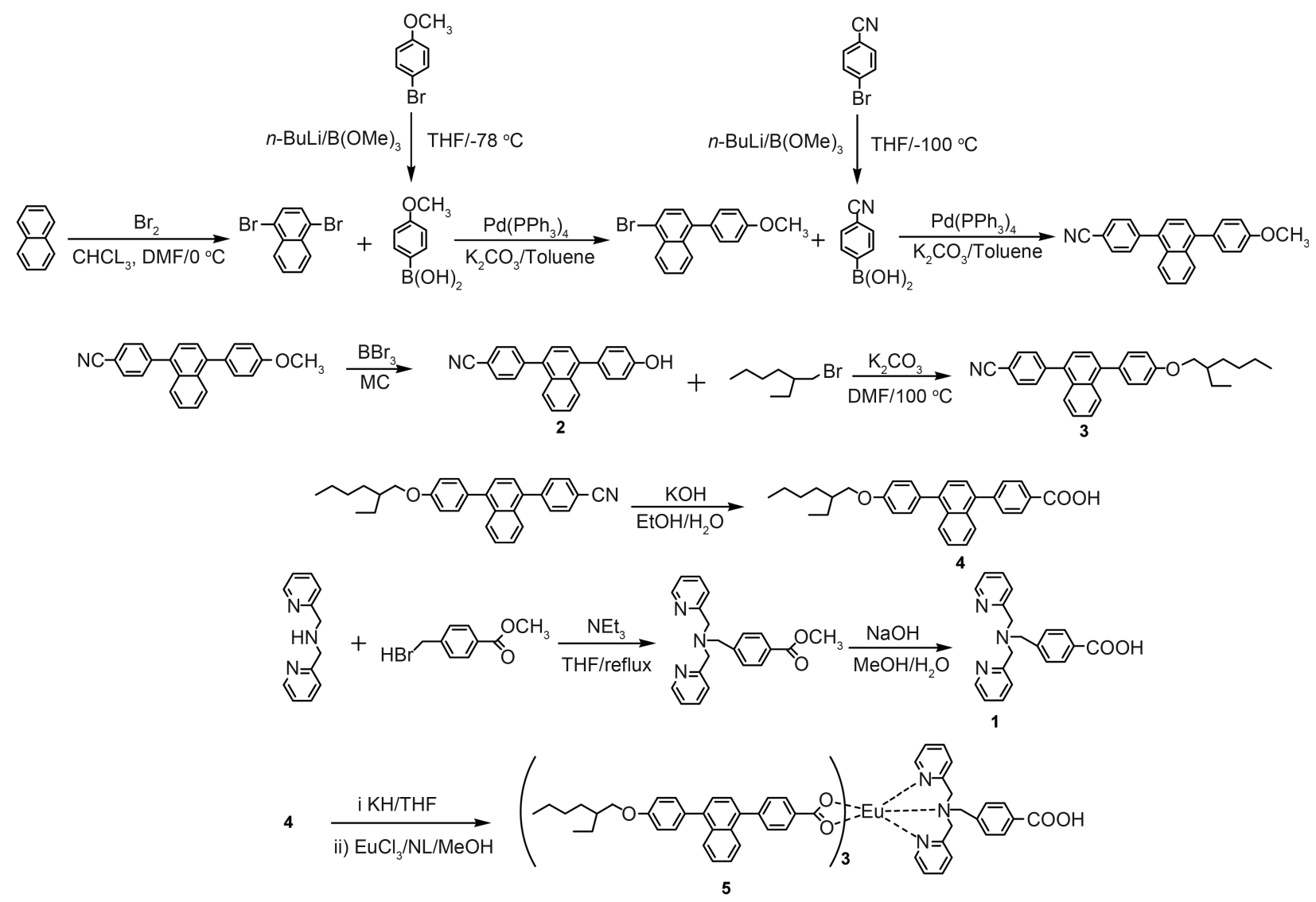

Scheme 3. Synthesis of wavelength conversion material based on lanthanide(III)-cored complex (WCM). 


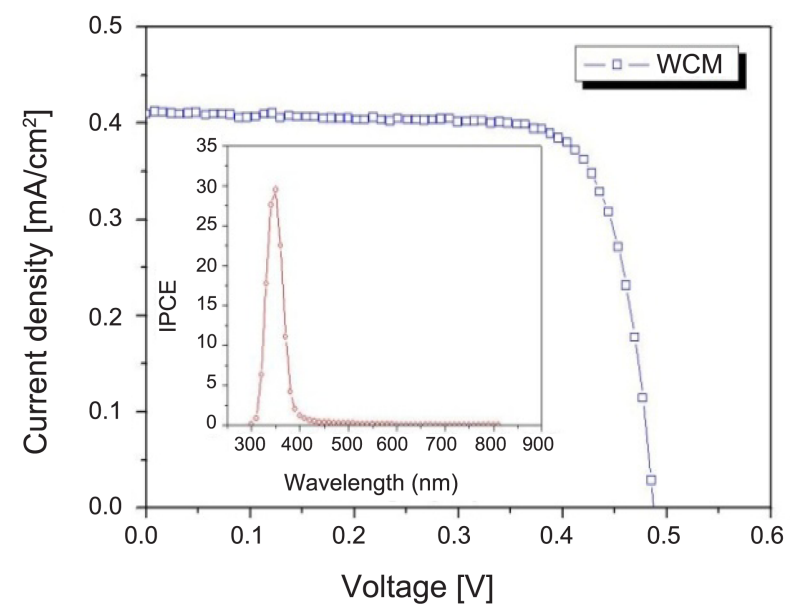

Figure 1. $J-V$ characteristic of $0.2 \mathrm{mM}$ WCM-based solar cell. The inset is its IPCE spectrum.

Novel lanthanide-cored complex with central and neutral ligands was synthesized by a ligand-exchange reaction developed in our laboratory, starting from $\mathrm{LnCl}_{3}(\mathrm{Ln}=\mathrm{Eu})$, and was obtained with $62-69 \%$ yields. ${ }^{28}$ All FT-IR spectra of the ligands exhibit a band around $1690-1720 \mathrm{~cm}^{-1}$ assigned to the vibration of carboxylic acid. In contrast, FT-IR spectra of the Eu complex exhibit two bands characteristic of asymmetric $\left(\sim 1600 \mathrm{~cm}^{-1}\right)$ and symmetric $\left(\sim 1400 \mathrm{~cm}^{-1}\right)$ stretching vibration modes of the carboxylate groups (Fig. S3 in ESI $\dagger$ ). These data indicate that the carboxylic acid groups have been quantitatively converted into carboxylate anions as a result of the formation of Eu complex.

Figure 1 shows $J-V$ characteristic of a WCM-based solar cell under standard test conditions (STC, AM 1.5 G, 100 $\mathrm{mW} \mathrm{cm}{ }^{-2}$ irradiation at $25^{\circ} \mathrm{C}$ ). The inset in the Figure 1 is an IPCE curve. To the best of our knowledge, it is the first time that WCM-based dye-sensitized solar cell is investigated. The photovoltaic performance of WCM-based solar cell was obtained with a short circuit current $\left(J_{\mathrm{sc}}\right)$ of $0.41 \mathrm{~mA} / \mathrm{cm}^{2}$, an open circuit voltage $\left(V_{\mathrm{oc}}\right)$ of $487 \mathrm{mV}$, a fill factor $(F F)$ of $77 \%$, and an overall energy conversion efficiency $(\eta)$ of $0.15 \%$ under standard AM 1.5 conditions. The maximum IPCE of WCM-based solar cell was ca. $30 \%$ at $350 \mathrm{~nm}$. These results indicate that lanthanide(III)-cored complex is not a good sensitizer for DSSC. The UV-vis spectra of black dye adsorbed on $\mathrm{TiO}_{2}$ photoanode at different co-adsorbents are shown in Figure 2. For black dye without DCA, the absorption peak around $350 \mathrm{~nm}$ was assigned to the $\pi-\pi^{*}$ absorption band and additionally two metal-to-ligand charge transfer (MLCT) transition bands were observed around 417 and $617 \mathrm{~nm}$. With the addition of DCA on the dye-adsorbed $\mathrm{TiO}_{2}$ film, no shift in absorption peak was observed.

However the absorbance at $617 \mathrm{~nm}$ decreased from 0.51 to 0.42 , suggesting that the amount of dye on the $\mathrm{TiO}_{2}$ surface decreased by $c a$. $17.6 \%$. On the other hand, the dye/WCMbased $\mathrm{TiO}_{2}$ film showed similar absorption peaks but showed a strong absorption peak around $355 \mathrm{~nm}$ from the WCM complex.

According to Figure 2, the absorbance of BD dye at 617

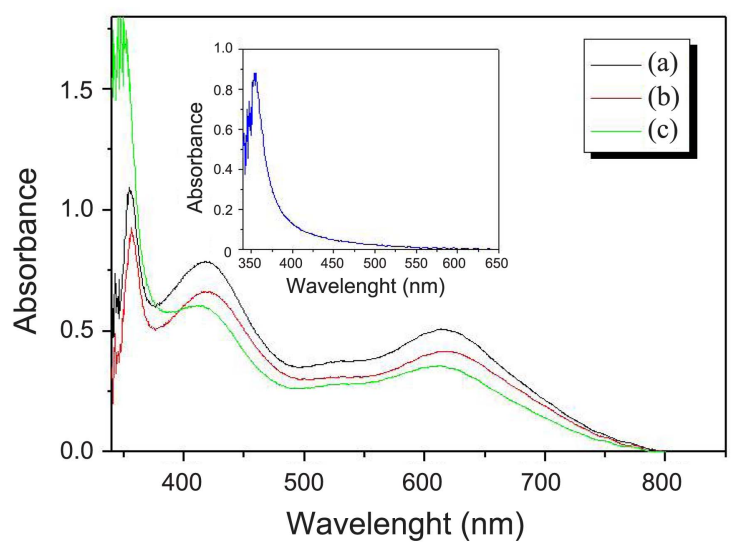

Figure 2. UV-vis absorption spectra for $\mathrm{TiO}_{2}$ films by dipping the films for $12 \mathrm{~h}$ with: (a) $0.2 \mathrm{mM}$ dye, (b) $0.2 \mathrm{mM}$ dye $+20 \mathrm{mM}$ DCA, (c) $0.2 \mathrm{mM}$ dye $+0.2 \mathrm{mM}$ WCM. The inset is an absorption spectrum of the $\mathrm{TiO}_{2}$ film adsorbed with WCM. The bare $\mathrm{TiO}_{2}$ transparent film was used as a reference for the spectrum scan.

$\mathrm{nm}$ decreased from 0.51 to 0.35 , indicating a $c a$. $31 \%$ drop in dye adsorption upon coadsorption with WCM complex. When dye with DCA or WCM was coadsorbed on the $\mathrm{TiO}_{2}$, the deprotonation of carboxylic acid group in the dye induces less adsorption of dye molecules on $\mathrm{TiO}_{2}$ surface due to the electro-static repulsion of negatively charged carboxylic groups. Moreover, the lower amount of dye adsorption with WCM complex than DCA, is mainly due to bigger molecular size of WCM. The competition of DCA or WCM with the dye for binding to the $\mathrm{TiO}_{2}$ surface is responsible for the decrease in dye adsorption. ${ }^{40,41}$ This might be correlated with dye- $\mathrm{TiO}_{2}$ interaction, dye-dye interactions, or both, and co-adsorption of WCM, like DCA, diminished these interactions on the $\mathrm{TiO}_{2}$ surface. ${ }^{25,42,43}$ Figure 3 shows the fluorescence emission of WCM only (black line) and that of WCM in the presence of BD (red line) in the EtOH/THF solvent. An emission peak at around $420 \mathrm{~nm}$ corresponds to the fluorescence emission of naphthalene ligand and other emission peaks were additionally observed at around 579, 588, 612,650, and $700 \mathrm{~nm}$, and are attributed to the $f-f$ transitions of ${ }^{5} \mathrm{D}_{0}{ }^{7} \mathrm{~F}_{J}$ with $J=0,1,2,3$ and 4 , respectively. ${ }^{39-44}$

The significant decrease in fluorescence emission of WCM at around $420 \mathrm{~nm}$ in the presence of BD was observed. It indicates that energy transfer may occur from naphthalene ligand in WCM to dye (ET3 pathway in Scheme 1). The fluorescence emission peak of the $\mathrm{Eu}^{3+}$ ions of WCM at around $620 \mathrm{~nm}$ disappeared in the presence of BD. This result also suggests that highly efficient energy transfer may take place from the $\mathrm{Eu}^{3+}$ ions to the $\mathrm{BD} .{ }^{45} \mathrm{As}$ a result, the conversion efficiency of DSSCs could be improved by utilizing the synergy effect of all the ET processes of the WCM as an alternative way to improve light harvesting, which absorbs light at shorter wavelengths and emits light at longer wavelengths. However, the more detailed kinetics for energy transfer processes between BD and WCM proposed here is complicated and another big research area, which is beyond the scope of this article and 
(a)

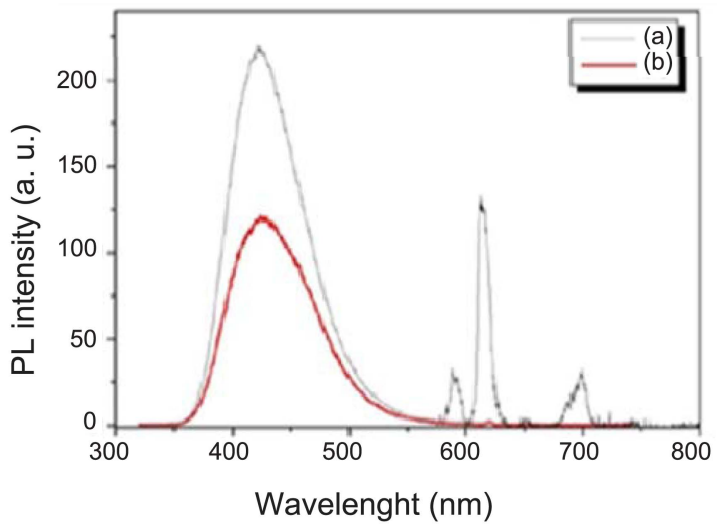

(b)

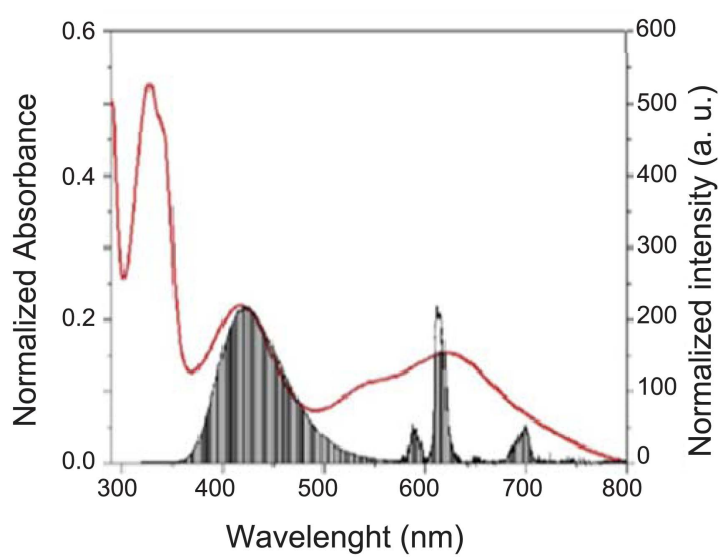

Figure 3. (a) PL emission spectra of WCM only (a) and WCM/ $\mathrm{BD}$ mixture (b) in EtOH/THF (concentration $=2 \times 10^{-5} \mathrm{M}, \lambda_{\mathrm{ex}}=$ $310 \mathrm{~nm}$ for $\mathrm{BD}$ and $\mathbf{W C M}$ ), (b) the spectral overlap integral between PL spectra of WCM (black) and the UV-vis absorption spectra of BD (red).

progressively being undertaken. In contrast to our results, recently, several research groups reported that efficient europium complexes physically adsorbed on a mesoscopic nanocrystalline $\mathrm{TiO}_{2}$ film, which was used as a host material for the lanthanide ion, were successfully prepared and europium emission was enhanced by energy transfer from $\mathrm{TiO}_{2}$ nanoparticles which act as antenna for the near UV excitation light of $300 \mathrm{~nm}$. Figure 4 shows the IPCE and $J-V$ characteristics of the DSSCs using different devices under standard test conditions. Their photovoltaic performance is summarized in Table 1. The IPCE of BD-based DSSC is lower than those of the others and is ascribed to charge recombination caused by dye molecules aggregation. However, in both case of DCA and WCM coadsorption, although the amount of dye on the $\mathrm{TiO}_{2}$ surface is reduced remarkably, the IPCE spectra become broader with the improved maximum IPCE. Compared with the maximum IPCE of the BD device, that of BD/WCM $(0.2 \mathrm{mM})$ exhibits ca. $23 \%$ higher value, even with its lower dye adsorbed amount.

The improvement in the IPCE by WCM, like DCA, could be correlated not only with a strong UV light-harvesting effect from the $\mathrm{Eu}(\mathrm{III})$-cored complex to $\mathrm{TiO}_{2}$ film via dye around 417 and $617 \mathrm{~nm}$, as shown in Scheme 1, but also
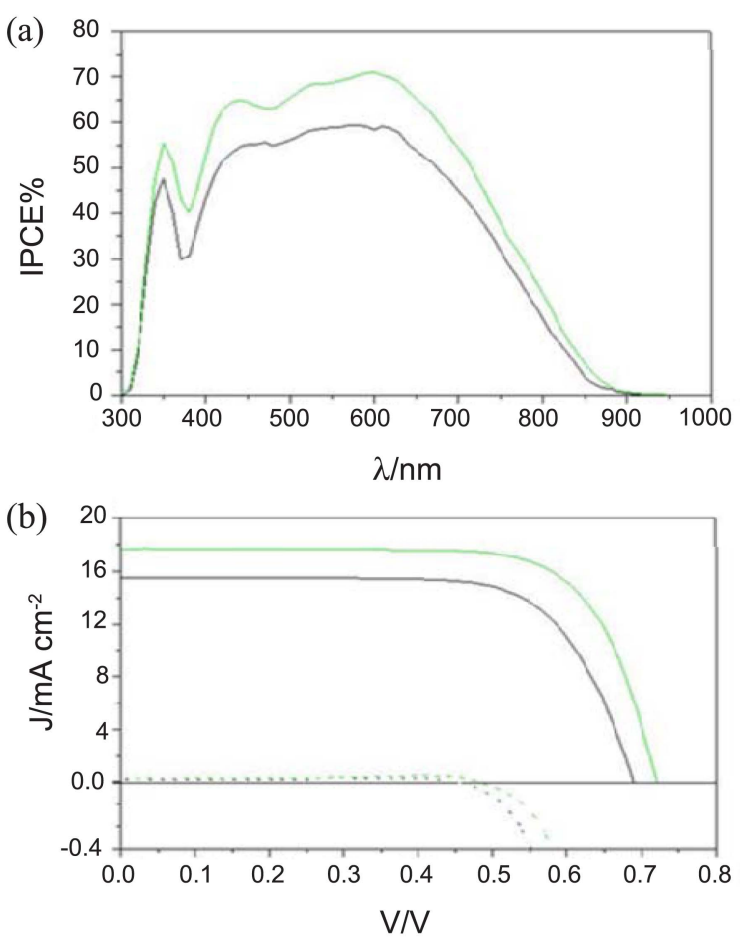

Figure 4. (a) IPCE spectra and b) $J-V$ curves of BD only (black line) and $\mathrm{BD}(0.2 \mathrm{mM}) / \mathbf{W C M}(0.2 \mathrm{mM})$ (green line). The darkcurrent/bias-potential relationship is shown as dotted curves.

with the suppression of the electron recombination between the injected electrons and $\mathrm{I}_{3}{ }^{-}$ions. The photovoltaic performance of the BD-based DSSC has lower values than those of the others, which influences the overall conversion efficiency $\left(\eta=V_{\mathrm{oc}} \times J_{\mathrm{sc}} \times F F\right)$. For the BD/DCA-based DSSC, compared with BD-based DSSC, $V_{\mathrm{oc}}$ increased from 689 to $722 \mathrm{mV}, J_{\mathrm{sc}}$ increased from 15.53 to $16.59 \mathrm{~mA} / \mathrm{cm}^{2}$, and the overall conversion efficiency increased from 7.58 to $8.54 \%$. $J_{\text {sc }}$ increased in the same order of integrated photocurrent from the IPCE spectrum. Meanwhile, for the BD/WCM-based DSSC, compared with BD/DCA-based DSSC, $V_{\mathrm{oc}}$ is almost same, but $J_{\mathrm{sc}}$ increased from 16.59 to $17.72 \mathrm{~mA} / \mathrm{cm}^{2}$, and the overall conversion efficiency increases from 8.54 to $9.28 \%$. Here, it should be addressed that higher WCM concentration should not be achieved, due to its limited solubility in the present DSSC fabrication condition. Thus, the coadsorption of either DCA or WCM improved $J_{\text {sc }}$ and $V_{\text {oc }}$, simultaneously, but coadsorption with WCM enhanced $J_{s c}$ more significantly than DCA. Compared with BD-based DSSC, $J_{s c}$ increased $6.4 \%$ for DCA and $12.4 \%$ for WCM coadsorption, respectively. Both DCA and WCM act as spacers between dye molecules and thus suppress the $\pi-\pi$ interaction between neighboring dye molecules, which retards charge recombination and hence improves photovoltaic performance, i.e., $J_{\mathrm{sc}}$ and $V_{\mathrm{oc}}$ significantly. It is worth noting that the short-circuit current is significantly increased by WCM without a significant change of open-circuit voltage, compared with DCA coadsorption. It may be due to the fact that electron transfer from the $\mathrm{Eu}^{3+}$ ions of WCM to dyes, so the injected 
(a)

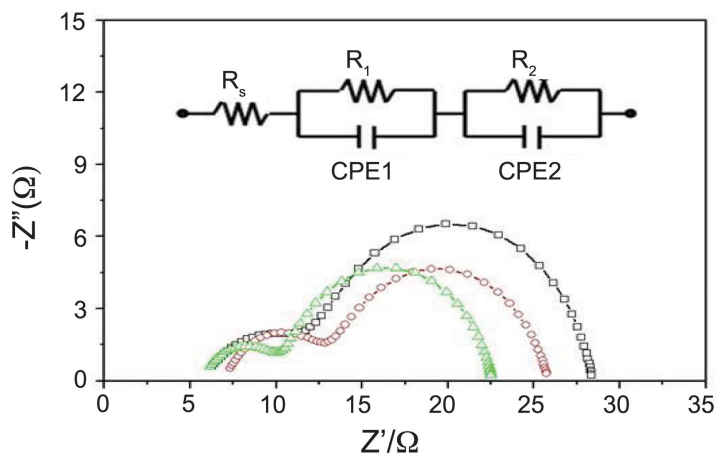

(b)

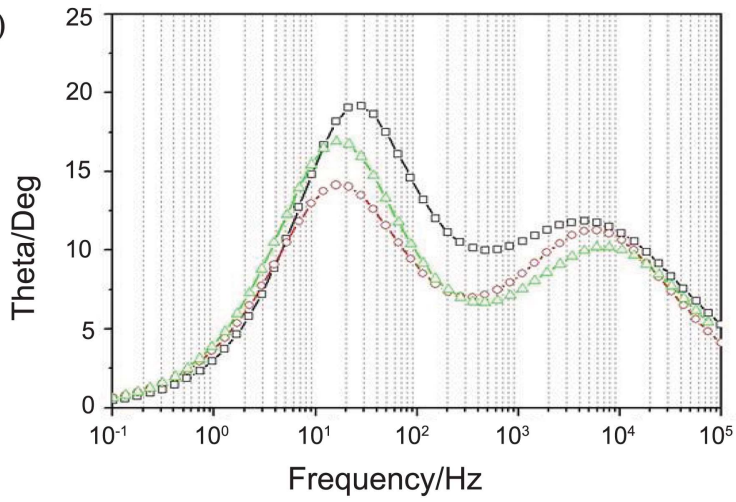

Figure 5. (a) Nyquist plots and (b) fitted Bode-phase plots of electrochemical impedance spectra measured under illumination $\left(100 \mathrm{~mW} \mathrm{~cm}^{-2}\right)$ for the DSSCs based on BD only (black line), BD $(0.2 \mathrm{mM}) / \mathrm{DCA}(20 \mathrm{mM})$ (red line), and BD $(0.2 \mathrm{mM}) / \mathbf{W C M}(0.2$ $\mathrm{mM})$ (green line).

electrons into the $\mathrm{TiO}_{2}$ surface are increased. This can be explained by the indirect evidence that BD/WCM-based solar cell has different IPCE spectrum from that of WCMbased solar through a strong UV light-harvesting effect from the $\mathrm{Eu}(\mathrm{III})$-cored complex to $\mathrm{TiO}_{2}$ film via dye around 417 and $617 \mathrm{~nm}$. As a consequence, WCM possibly acts as a spacer to prevent dye aggregation and also as a promising photosensitizer for dyes through energy transfer from lanthanide ions under UV light excitation. Thus, all synergy effects play a major role for achieving highly efficient DSSCs. In contrast, recently, several research groups reported that efficient europium complexes physically adsorbed on a mesoscopic nanocrystalline $\mathrm{TiO}_{2}$ film, which was used as a host material for the lanthanide ion, were prepared and europium emission was enhanced by energy transfer from $\mathrm{TiO}_{2}$ nanoparticles which act as antenna for the near UV excitation light of $300 \mathrm{~nm} .{ }^{46-48}$ In order to get further insight for understanding the improvement of DSSC by WCM, the electrochemical impedance spectroscopy was meaured under illumination of simulated AM 1.5 light $\left(100 \mathrm{~mW} \mathrm{~cm}^{-2}\right)$. Figure 5 shows the AC impedance spectra of the DSSCs at open-circuit voltage condition. The results are based on the equivalent circuit shown as the inset in Figure 5. Responses in the frequency regions of $10^{3}-10^{5}, 1-10^{3}$, and 0.1-1 Hz are assigned to charge-transfer processes occurring at the Pt/electrolyte interface, $\mathrm{TiO}_{2} /$ dye/electrolyte interface, and the Nernst diffusion within the electrolyte, respectively. ${ }^{49,50}$

The resistance at the $\mathrm{TiO}_{2} /$ dye/electrolyte interface was decreased to some extent upon DCA and WCM coadsorption, indicating the improved electron generation and transport. These results reflect well-known trends observed in the short circuit photocurrent density (Table 1). Electron lifetime $\left(\tau_{\mathrm{e}}\right)$ in the $\mathrm{TiO}_{2}$ film can be obtained from the characteristic frequency angle $\left(\omega_{\mathrm{mid}}\right)$ of the mid-frequency peak $\left(f_{\text {mid }}\right)$ of the bode-phase plots, from the equation of $\tau_{\mathrm{e}}=$ $1 / \omega_{\text {mid }}=1 / 2 \pi f_{\text {mid. }}{ }^{51-55}$ Both the maximum $f_{\text {mid }}$ of BD/DCA and BD/WCM-based DSSCs were shifted to low frequency region. BD-based DSSC without coadsorbent exhibits the maximum $f_{\text {mid }}$ of $c a .27 .8 \mathrm{~Hz}$, but BD/DCA and BD/WCM show the maximum $f_{\text {mid }}$ of $c a$. $16.4 \mathrm{~Hz}$. These results show that $\mathrm{BD} / \mathrm{DCA}$ and $\mathrm{BD} / \mathbf{W C M}$-based devices present the longer electron lifetime of $9.7 \mathrm{~ms}$ which is increased by a factor of $c a$. 1.7, when compared with BD-based DSSC. These results demonstrate that DCA and WCM in DSSCs decreases the charge recombination between injected electrons and oxidized dye or redox couple, resulting in the large open circuit voltage of $V_{\mathrm{oc}}$ for $\mathrm{BD} / \mathrm{DCA}$ and $\mathrm{BD} /$ WCM-based devices.

\section{Conclusion}

We have just demonstrated that a lanthanide(III)-cored complex for achieving highly efficient dye-sensitised solar cells has multiple functioned effects, that is, the prevention effect of the $\pi-\pi$ stacking of black dye and the light harvesting effect at shorter-wavelength regions through energy transfer from lanthanide ions under UV light excitation. The overall conversion efficiency of the BD/WCM device was remarkably increased, even with its relatively small adding amount of WCM. The enhancement in the $V_{\text {oc }}$ by WCM, like DCA, could be correlated with the suppression of the electron recombination between the injected electrons and $\mathrm{I}_{3}{ }^{-}$ions. Furthermore, the short-circuit current density is significantly increased by WCM with a strong UV light-harvesting effect. The energy transfer from the Eu(III)-cored complex to $\mathrm{TiO}_{2}$ film via dye, so the injected electrons into the $\mathrm{TiO}_{2}$ surface are increased, i.e., short-circuit current density is increased. Thus, the $\mathrm{Eu}(\mathrm{III})$-cored complex is a promising candidate as a new wavelength conversion coadsorbent for highly efficient dye-sensitized solar cells to improve UV light harvesting through energy transfer process. The more detailed kinetics for energy transfer processes between BD and WCM proposed here is complicated and another big research area, which is beyond the scope of this article and progressively being undertaken.

Acknowledgments. This research was supported by MKE, Korea, under the ITRC support program supervised by the NIPA (National IT Industry Promotion Agency) (NIPA-2011-C1090-1121-0004), WCU program (R31-2008000-10035-0) and by the Converging Research Center Program through the National Research Foundation of Korea (NRF) (2011K000973). 
Supporting Information Available: Details of photophysical properties and characterization This material is available free of charge via the Internet at http:// journal.kcsnet.or.kr.

\section{References}

1. Kim, H. K.; Roh, S.-G.; Hong, K.-S.; Ka, J.-W.; Baek, N. S.; Oh, J. B.; Nah, M. K.; Cha, Y. H.; Ko, J. Macromol. Res. 2007, 5, 272.

2. Kim, H. K.; Oh, J. B.; Baek, N. S.; Roh, S.-G.; Nah, M. K.; Kim,Y. H. Bull. Korean Chem. Soc. 2005, 26, 201.

3. Eliseeva, S. V.; Bünzli, J.-C. G. New J. Chem. 2011, DOI: 10.1039/ c0nj00969e (published on the web, February 2, 2011.

4. Bünzli, J.-C. G.; Eliseeva, S. V. J. Rare Earths. 2010, 28, 824.

5. Eliseeva, S. V.; Bünzli, J.-C. G. Chem. Soc. Rev. 2010, 39, 189.

6. Rocha, J.; Carlos, L. D.; Paz, F. A. A.; Ananias, D. Chem. Soc. Rev. 2011, 40, 926.

7. Oyamada, T.; Kawamura, Y.; Koyama, T.; Sasabe, H.; Adachi, C. Adv. Mater. 2004, 16, 1082.

8. Kang, T.-S.; Harrison, B. S.; Bouguettaya, M.; Foley, T. J.; Boncella, J. M.; Schanze, K. S.; Reynolds, J. R. Adv. Funct. Mater. 2003, 13, 205.

9. O’Reagen, B.; Grätzel, M. Nature 1991, 353, 737.

10. Grätzel, M. Nature 2001, 414, 338.

11. Wang, P.; Klein, C.; Baker, R. H.; Zakeeruddin, S. M.; Grätzel, M. J. Am. Chem. Soc. 2005, 127, 808 .

12. Jang, S. R.; Lee, C. C.; Choi, H.; Ko, J. J.; Lee, J.; Vittal, R.; Kim, K. J. Chem. Mater. 2006, 18, 5604.

13. Robertson, N. Angew. Chem. Int. Ed. 2006, 45, 1611.

14. Nazeeruddin, M. K.; Angelis, F. De; Fantacci, S.; Selloni, A.; Viscardi, G.; Liska, P.; Ito, S.; Bessho, T.; Grätzel, M. J. Am. Chem. Soc. 2005, 127, 16835.

15. Grätzel, M. J. Photochem. Photobiol. 2003, C4, 145.

16. Grätzel, M. Prog. Photovolt Res. Appl. 2006, 14, 429

17. Choi, H.; Baik, C.; Kang, S. O.; Ko, J.; Kang, S. M.; Nazeeruddin, M. K.; Grätzel, M. Angew. Chem. Int. Ed. 2008, 47, 327.

18. Palomares, E.; Clifford, J. N.; Haque, S. A.; Lutz, T.; Durrant, J. R. J. Am. Chem. Soc. 2003, 125, 475.

19. Chen, S. G.; Chappel, S.; Diamant, Y.; Zaban, A. Chem. Mater. 2001, 13, 4629.

20. Wang, P.; Zakeeruddin, S. M.; Comte, P.; Charvet, R.; HumphryBaker, R.; Grätzel, M. J. Phys. Chem. B 2003, 107, 14336.

21. Wang, P.; Zakeeruddin, S. M.; Humphry-Baker, R.; Moser, J. E.; Grätzel, M. Adv. Mater. 2003, 15, 2101.

22. Wang, P.; Zakeeruddin, S. M.; Humphry-Baker, R.; Grätzel, M. Chem. Mater. 2004, 16, 2694.

23. Kopidakis, N.; Neale, N. R.; Frank, A. J. J. Phys. Chem. B 2006, 110,12485

24. Pelet, J. S.; Moser, E.; Grätzel, M. J. Phys. Chem. B 2000, 104, 1791.

25. Hara, K.; Dan-oh, Y.; Kasada, C.; Ohga, Y.; Shinpo, A.; Suga, S.; Sayama, K.; Arakawa, H. Langmuir 2004, 20, 4205.

26. Nazeeruddin, M. K.; Pe'chy, P.; Renouard, T.; Zakeeruddin, S. M.; Humphry-Baker, R.; Comte, P.; Liska, P.; Cevey, E.; Le. Costa, Shklover, V.; Spiccia, L; Deacon, G. B.; Bignozzi, C. A.; Grätzel, M. J. Am. Chem. Soc. 2001, 123, 1613.

27. Chiba, Y.; Islam, A.; Watanabe, Y.; Komiya, R.; Koide, N.; Han,
L. J. App. Phys. 2006, 45, L638.

28. Baek, N. S.; Yum, J.-H.; Kim, H. K.; Nazeeruddin, M. K.; Grätzel, M. Energy Environ. Sci. 2009, 2, 1082.

29. Seo, K. D.; Song, H. M.; Lee, M. J.; Pastore, M.; Anselmi, C.; Angelis, F. D.; Nazeeruddin, M. K.; Grätzel, M.; Kim, H. K. Dyes and Pigments 2011, 90, 304.

30. Lee, K.-M.; Suryanarayanan, V.; Ho, K.-C.; Justin Thomas, K. R.; Lin, J. T. Sol. Energy. Mater. Sol. Cells 2007, 91, 1426.

31. Snaith, H. J. Adv. Funct. Mater. 2010, 20, 13.

32. Kane-sato, M.; Sugaya, K.; Segawa, Tsukada, M. N. PCT/JP2006/ 319848.

33. Kane-sato, M.; Sugaya, K.; Segawa, M. PCT/JP2006/320762.

34. Kim, Y. H.; Baek, N. S.; Kim, H. K. ChemPhysChem. 2006, 7, 213.

35. Baek, N. S.; Kim, Y. H.; Roh, S.-G.; Lee, D. H.; Seo, K. D.; Kim, H. K. Bull. Kor. Chem. Soc. 2009, 7, 1553.

36. Baek, N. S.; Kim, Y. H.; Roh, S. G.; Kwak, B. K.; Kim, H. K. Adv. Funct. Mater. 2006, 16, 1873.

37. Bünzli, J.-C. G.; Chauvin, A-S.; Deiters, E.; Eliseeva, S. V.; Kim, H. K. Coord. Chem. Rev. 2010, 254, 2623.

38. Oh, J. B.; Nah, M. K.; Kim, Y. H.; Kang, M. S.; Ka, J. W.; Kim, H. K. Adv. Funct. Mater. 2007, 17, 413.

39. Ren, X.; Feng, Q.; Zhou, G.; Huang, C.-H.; Wang, Z.-S. J. Phys. Chem. C 2010, 114, 7190 .

40. (a) Bernard, M. C.; Cachet, H.; Falaras, P.; Hugot-Le Goff, A.; Kalbac, M.; Lukes, I.; Oanh, N. T.; Stergiopoulos, T.; Arabatzis, I J. Electrochem. Soc. 2003, 150, E1159. (b) Prodi, A.; Chiorboli, C.; Scandola, F.; Iengo, E.; Alessio, E.; Dobrawa, R.; Würthner, F. J. Am. Chem. Soc. 2005, 127, 1454.

41. Kamart, P. V. Chem. Rev. 1993, 93, 267.

42. Baek, N. S.; Kim, Y. H.; Eom, Y. K.; Oh, J. H.; Kim, H. K.; Aevisscher, A.; Fèrèderic, G.; Chauvin, A.-S.; Bünzli, J.-C. G. Dalton Trans. 2010, 39, 1532.

43. Nah, M. K.; Oh, J. B.; Kim, H. K.; Choi, K.-H.; Kim, Y.-R.; Kang, J.-G. J. Phys. Chem. A 2007, 111, 6157.

44. Van staveren, D. R.; Bothe, E.; Weyhermüller, T.; Metzler-Nolte, N. Eur. J. Inorg. Chem. 2002, 6, 1518.

45. Hardin, B. E.; Hoke, E. T.; Armstrong, P. B.; Yum, J. H.; Comte, P.; Torres, T.; Frechet, J. M. J.; Nazeeruddin, M. K.; Grätzel, M.; McGehee, M. D. Nature photonics 2009, 3, 406.

46. Stathatos, E. Int. J. Mod. Phys. B 2006, 20, 249.

47. Frindell, K. L.; Bartl, M. H.; Popitsch, A.; Stucky, G. D. Angew. Chem. Int. Ed. 2002, 41, 960.

48. Li, H.; Inoue, S.; Machida, K.; Adachi, G. Chem. Mater. 1999, 11, 3171.

49. Hara, K.; Sato, T.; Katoh, R.; Furube, A.; Ohga, Y.; Shinpo, A.; Suga, S.; Sayama, K.; Sugihara, H.; Arakawa, H. J. Phys. Chem. $B$ 2003, 107, 597.

50. Koops, S. E.; Barnes, P. R. F.; O'Regan, B.; Durrant, J. R. J. Phys. Chem. C 2010, 114, 8054.

51. Kern, R.; Sastrawan, R.; Ferber, J.; Stangl, R.; Luther, J. Electrochem. Acta. 2002, 47, 4213.

52. Bisquert, J. J. Phys. Chem. B 2002, 106, 325.

53. Bisquert, J. Phys. Chem. Chem. Phys. 2003, 5, 5360.

54. Wang, N.; Lin, H.; Li, J.; Li, X. Appl. Phys. Lett. 2006, 89, 194104.

55. Jiangbin, X.; Masaki, N.; Lira-Cantu, M.; Kim, Y.; Jiang, K.; Yanagida, S. J. Am. Chem. Soc. 2008, 130, 1258. 